\title{
Myenteric plexus is differentially affected by infection with distinct Trypanosoma cruzi strains in Beagle dogs
}

\author{
Nívia Carolina Nogueira-Paiva', Kátia da Silva Fonseca', Paula Melo de Abreu Vieira, ${ }^{1}$, \\ Lívia Figueiredo Diniz², Ivo Santana Caldas², Sandra Aparecida Lima de Moura ${ }^{3,6}$, \\ Vanja Maria Veloso ${ }^{4}$, Paulo Marcos da Matta Guedes ${ }^{5}$, Washington Luiz Tafuri' ${ }^{1+}$, \\ Maria Terezinha Bahia ${ }^{2,6}$, Cláudia Martins Carneiro' ${ }^{1,7} /+$
}

\author{
'Laboratório de Imunopatologia ${ }^{1}$ Laboratório de Doença de Chagas ${ }^{3}$ Laboratório de Imunoparasitologia, \\ Núcleo de Pesquisas em Ciências Biológicas ${ }^{6}$ Departamento de Ciências Biológicas, Instituto de Ciências Exatas e Biológicas \\ ${ }^{4}$ Departamento de Farmácia ${ }^{7}$ Departamento de Análises Clínicas, Escola de Farmácia, Universidade Federal de Ouro Preto, \\ Ouro Preto, MG, Brasil ${ }^{5}$ Departamento de Microbiologia e Parasitologia, Universidade Federal do Rio Grande do Norte, Natal, RN, Brasil
}

Chagasic megaoesophagus and megacolon are characterised by motor abnormalities related to enteric nervous system lesions and their development seems to be related to geographic distribution of distinct Trypanosoma cruzi subpopulations. Beagle dogs were infected with Y or Berenice-78 (Be-78) T. cruzi strains and necropsied during the acute or chronic phase of experimental disease for post mortem histopathological evaluation of the oesophagus and colon. Both strains infected the oesophagus and colon and caused an inflammatory response during the acute phase. In the chronic phase, inflammatory process was observed exclusively in the Be-78 infected animals, possibly due to a parasitism persistent only in this group. Myenteric denervation occurred during the acute phase of infection for both strains, but persisted chronically only in Be-78 infected animals. Glial cell involvement occurred earlier in animals infected with the $Y$ strain, while animals infected with the Be-78 strain showed reduced glial fibrillary acidic protein immunoreactive area of enteric glial cells in the chronic phase. These results suggest that although both strains cause lesions in the digestive tract, the Y strain is associated with early control of the lesion, while the Be-78 strain results in progressive gut lesions in this model.

Key words: dog - Trypanosoma cruzi - myenteric plexus

Chagas disease (ChD) has two clinically recognised phases during its natural evolution. Following Trypanosoma cruzi infection, the acute phase is characterised by high parasitaemia, intense tissue parasitism and inflammatory process in different organs. This phase also includes the development of autonomic nervous system lesions that are usually related to an adjacent inflammatory infiltrate, with or without amastigote nests. The chronic phase begins when the host immune system controls the parasite replication, leading to decreased parasitaemia and tissue parasitism and subsequent inflammatory process reduction (Chagas 1909, Tafuri 1971, Tafuri et al. 1971, Prata 2001). After several years of infection, approximately $30 \%$ of infected individuals may present morphofunctional changes in some organs that evolves to ChD symptomatic or determinate form. The maintenance of an active and progressive inflammatory response is associated with severe $\mathrm{ChD}$ alterations, in which the most common clinical manifestations involve

doi: 10.1590/0074-0276130216

Financial support: UFOP, FAPEMIG, CNPq, CAPES

+In memoriam

+ Corresponding author: carneirocm@gmail.com

Received 19 April 2013

Accepted 21 August 2013 the heart and/or digestive tract (Tafuri 1971). However, other T. cruzi-infected individuals may remain asymptomatic for the rest of their lives, which is the most frequent anatomoclinical form, known as indeterminate ChD (Andrade 1985, Prata 2001, Andrade 2005).

Histologically, focal inflammatory infiltrates can be observed in the asymptomatic form regardless of parasite presence. Thus, indeterminate $\mathrm{ChD}$ seems to have a complex anatomoclinical and epidemiological significance and may represent only a phase or a latent form, in spite of normal radiological and electrocardiographic chest tests, histological lesions may be present in these individuals and may indicate progression to the determinate form even at low levels (Coura et al. 1985, Castro et al. 1994, Prata 2001). Supporting this hypothesis, a longitudinal study from 1975-1991 in the city of Mambaí, state of Goiás, Brazil revealed that $32.5 \%$ of $\mathrm{ChD}$ indeterminate patients showed disease progression, with most of them eventually presenting signs and symptoms of the digestive form (Castro et al. 2001). Other studies show that morphological changes to the colon, such as solitary distal colon lengthening (dolichocolon), with or without symptoms, have a high prevalence among seropositive $T$. cruzi patients and may strongly indicate that lengthening precedes dilatation, a typical manifestation of chagasic megacolon (Castro et al. 2012).

The development of the digestive form, represented mainly by megaoesophagus and megacolon, seems to be related to the geographic distribution of different sub- 
populations of T. cruzi (Zingales et al. 1998, Prata 2001, Virreira et al. 2006). Anatomically, the affected organs show areas with variable degrees of dilatation interspersed with normal-appearing areas, lumen increase, absence of mechanical obstruction and wall thickening especially related to muscle hypertrophy (Tafuri 1970, Adad et al. 1991)

The pathogenic mechanisms of digestive lesions are not yet fully understood; however, during the acute phase, neuronal damage could be caused by direct or indirect tissue effects of parasitism and subsequent inflammatory response in regions close to the enteric ganglia (Köberle \& Alcântara 1960, Teixeira et al. 1970, Ribeiro Dos Santos \& Hudson 1980, 1981). According to Tafuri (1971), acute enteric nervous system (ENS) changes in digestive $\mathrm{ChD}$ are related to organ motor dysfunction that results in accumulation of food or faeces in the lumen, which can compress the mucosa and induce dilation and ischemic events. These events, in turn, can cause regressive lesions of the mucosa and an inflammatory process that reaches the submucosa, leading to submucous plexus injuries and then the muscularis, reaching the myenteric plexus already injured by acute infection. The accumulation and maintenance of the inflammatory cells throughout the chronic disease are associated with tissue destruction and disease progression to fibrosis, which is one of the factors responsible for modification of the intermuscular interstitium components. The involvement of the ENS during the course of T. cruzi infection has been shown in many studies using immunohistochemistry techniques with multiple markers and histopathological findings show that the effects are not restricted to neuronal damage, since changes in enteric glial cell (EGC) numbers and phenotype are also observed (da Silveira et al. 2007, 2009, Iantorno et al. 2007). Thus, patients with megaoesophagus and/or megacolon show reductions in neurons (Adad et al. 2001, da Silveira et al. 2005) and nerve fibres (da Silveira et al. 2007), moreover, there is loss of $\mathrm{S} 100^{+}$glial cells (da Silveira et al. 2007, Iantorno et al. 2007).

Studies in cell culture have confirmed the existence of two types of EGCs, EGC-glial fibrillary acidic protein $(G F A P)^{+}$and the EGC-GFAP- They have also shown that increased expression of GFAP, interpreted as a response to trauma, is associated with the pro-inflammatory cytokines tumour necrosis factor- $\alpha$ and interleukin- $1 \beta$ (Von Boyen et al. 2004), with expression possibly related to increased cohesion between glial cells (Buniatian et al. 2002). da Silveira et al. $(2007,2009)$ observed a glial cell $\mathrm{GFAP}^{+}$increase in chagasic patients regardless of colon involvement; however, GFAP expression was higher in the nondilated colon. This suggests that intermediate filament expression might underlie a protective barrier for the cell bodies of the neurons and represent an attempt at protection against the inflammatory process or parasite infection. The increase in glial cells was also related to lower inflammatory infiltrates and thus to lower levels of neuronal damage, less dilatation of the organ and the absence of megaoesophagus pathophysiological manifestations (Nascimento et al. 2010). In this sense, EGC expansion, although it cannot prevent the parasite invasion (da Silveira et al. 2005), may help to control the inflammatory process by preventing injuries associated with denervation, swelling and organ function loss (Nascimento et al. 2010).

Given the scarcity of experimental models to study digestive tract changes in $\mathrm{ChD}$ and similarities in disease progression in a canine model (Canis familiaris) (de Lana et al. 1988, 1992, Caliari et al. 1996, Machado et al. 2001), as well as the potential role of ENS components in the development of the digestive form of $\mathrm{ChD}$, this study evaluated the profile of changes that occurred in the oesophagus and colon of Beagle dogs after infection with two morphologically distinct $T$. cruzi subpopulations belonging to the discrete typing unit (DTU) TcII.

\section{MATERIALS AND METHODS}

All procedures and experimental protocols were conducted in accordance with the directives issued by the Brazilian College of Animal Experimentation and approved by the Ethical Committee in Animal Research at Federal University of Ouro Preto (UFOP), state of Minas Gerais, Brazil (protocol 2006/69). Animals were fed with commercial dog food and water ad libitum. Prior to the study, the animals were dewormed and vaccinated against several infectious diseases.

T. cruzi strains - T. cruzi strains used in this study belong to DTU TcII (Zingales et al. 2009) and exhibit distinct morphological characteristics (Guedes et al. 2007). The Berenice-78 strain (Be-78) (predominantly composed by stout trypomastigotes forms) was isolated by xenodiagnosis in 1978 (de Lana \& Chiari 1986) from the first human case of $\mathrm{ChD}$, while the Y strain (predominantly composed by slender trypomastigotes forms) was isolated from an acute human case and later described by Silva and Nussenzweig (1953).

Animals and experimental infection - Twenty-four four-month-old Beagles from the UFOP kennel were distributed into three experimental groups: noninfected (NI) $(\mathrm{n}=8)$, infected with the $\mathrm{Y}$ strain $(\mathrm{Y})(\mathrm{n}=8)$ and infected with the Be-78 strain $(\mathrm{Be}-78)(\mathrm{n}=8)$. The infected groups were inoculated intraperitoneally with $4.0 \times 10^{3}$ bloodstream trypomastigotes of Be-78 or Y T. cruzi strains per kilogram of body weight, while eight age-matched NI dogs were used as controls.

Necropsy of the animals and tissue samples - Four animals from each experimental group were euthanised by injection with thionenbutal (Abbott, São Paulo, Brazil) $0.5 \mathrm{~mL} / \mathrm{kg}$ of body weight $(0.03 \mathrm{~g} / \mathrm{mL}$ in $0.8 \%$ saline solution) 30 or 720 days after infection during the acute or chronic phases, respectively. During necropsy, segments of the oesophagus and colon were excised and frozen at $-80^{\circ} \mathrm{C}$ or preserved in $3.7 \%$ buffered formalin (pH 7.2) and embedded in paraffin.

Tissue parasitism - Tissue parasitism was evaluated in frozen samples submitted to kDNA parasite detection by polymerase chain reaction (PCR). Oesophagus and colon samples were thawed, minced and subjected to DNA extraction by Wizard Kit $\left(\right.$ Promega $\left.^{\circledR}\right)$ following 
the manufacturer's instructions. PCR amplification was performed in a total volume of $11 \mu \mathrm{L}$ containing $0.1 \%$ Triton X-100, $10 \mathrm{mM}$ Tris-HCl (pH 9.0), $75 \mathrm{mM} \mathrm{KCl,}$ $5 \mathrm{mM} \mathrm{MgCl}, 0.25 \mathrm{mM}$ (each) dATP, dTTP, dGTP and dCTP (Sigma Company Ltd, USA), 0.5 U of Taq DNA polymerase (Platinum, Invitrogen, SP, Brazil), $10 \mathrm{pmol}$ of S35 (5'AAATAATGTACGGG(T/G)GAGATGCATGA3') and S36 (5'GGGTTCGATTGGGGTTGGTGT 3') primers and $2 \mu \mathrm{L}$ of DNA for each sample (Ávila et al. 1990). The reaction mixture was overlaid with $30 \mu \mathrm{L}$ of mineral oil (Sigma) and subjected to 35 cycles of amplification in an automatic thermocycler (MJ Research programmable thermal controller PTC-100). The temperature profile was as follows: denaturation at $95^{\circ} \mathrm{C}$ for 1 $\min$ (with a longer initial time of $5 \mathrm{~min}$ at $95^{\circ} \mathrm{C}$ ), $65^{\circ} \mathrm{C}$ for $1 \mathrm{~min}$ for primer annealing and $72^{\circ} \mathrm{C}$ for $1 \mathrm{~min}$ for extension, with a final incubation at $72^{\circ} \mathrm{C}$ for $10 \mathrm{~min}$ to extend the annealed primers. The PCR products were visualised by $6 \%$ polyacrylamide gel electrophoresis followed by silver staining (Santos et al. 1993). All DNA extraction steps and reaction mixtures used for PCR were monitored and compared to positive and negative controls.

Inflammatory process - Paraffin-embedded oesophagus and colon tissues were sliced into $4-\mu \mathrm{m}$-thick sections, mounted onto albumin-coated glass slides and stained by haematoxylin-eosin for inflammatory infiltrate quantification.

Collagen neoformation - Fibrosis process was determined by total soluble collagen quantified in the oesophagus and colon frozen samples through biochemical analysis based on the collagen precipitation by Sirius red reagent (Mendes et al. 2009b) and qualitative assessment of microscopic sections of cross-sections $(4 \mu \mathrm{m})$ stained with Picrosirius red obtained with a planapochromatic objective 10X (100X) in light microscopy (Moura et al. 2009).

Auerbach plexus - Paraffin-embedded oesophagus and colon tissues sliced into $4-\mu \mathrm{m}$-thick sections were mounted onto silanised-coated glass slides and subjected to immunohistochemistry studies of Auerbach's plexus components. The sections deparaffinised through xylene and dehydrated in graded alcohols were heated at $90^{\circ} \mathrm{C}$ for $20 \mathrm{~min}$ for antigen retrieval with citrate buffer, followed by endogenous peroxidase activity inhibition by double incubation with $3 \%$ hydrogen peroxide in absolute methanol for $30 \mathrm{~min}$. Next, blocking of nonspecific sites was carried out in two steps, the first consisting of a bath with milk powder $(0.1 \mathrm{mg} / \mathrm{mL})\left(\right.$ Molico $^{\circledR}$, Nestlé, Brazil) followed by incubation with normal goat serum $(1: 50)$ at $25^{\circ} \mathrm{C}$. The slides were then incubated overnight at $4^{\circ} \mathrm{C}$ with monoclonal antibodies specific to PGP9.5 (1:100) (Z5116-Dako Cytomation, USA) and GFAP (1:50) (Z03334-Dako Cytomation) and submitted to incubation with peroxidase-conjugated rabbit antimouse antibodies (K0675-Dako Cytomation) for $60 \mathrm{~min}$. Peroxidase activity was demonstrated by incubation with $3.3 \mathrm{k}$-diaminobenzidine (Sigma) and hydrogen peroxide for $5 \mathrm{~min}$. Slides were counterstained with Harry's haematoxylin, dehydrated in graded alcohols and mounted in synthetic mounting media.
Morphometric analyses - Morphometric analyses of the inflammatory infiltrate, Auerbach plexus innervation [PGP9.5-immunoreactive (IR) area] and enteroglial components (GFAP-IR area) were carried out. All tests were performed in a single slide of tissue sections from each animal. Sections were viewed with a 40X objective and images were digitised by Leica DFC340FX microcamera associated with Leica DM5000B microscopy; all images were analysed using the image processing and analysis software Leica Qwin V3 at Multiuser Laboratory of Center for Research in Biological Sciences of UFOP. The inflammatory process was assessed by cell nuclei quantification in the submucous and muscular layers in 20 random images (fields) covering a total area equal to $1.5 \times 10^{6} \mu \mathrm{m}^{2}$ and the difference $(\mathrm{p}<0.05)$ between the number of cell nuclei present in the animals infected with $T$. cruzi and that observed in NI animals (cut-off) determined the number of inflammatory cells (Caliari et al. 1996, Maltos et al. 2004). The images number was determined by stability statistical test draw at random replacement. In the Auerbach plexus, the neuron numbers and morphology, PGP9.5-IR area and $\mathrm{GFAP}^{+}$area were evaluated. In ganglion neurons, the measurements of the cell body and the nuclear and cytoplasmic area and perimeter, in addition to the ratios between the nuclear and cell body area, were assessed (Barbosa et al. 2009, Mendes et al. 2009a). In addition, the number of intact neurons was quantified and evaluated in relation to the ganglionic area (Tafuri 1957). The innervation of the myenteric plexus was analysed by measuring the PGP9.5-IR area restricted to and relative to the ganglionic area. Morphometric analysis of the enteroglial components was performed by assessment of the GFAP-IR area restricted to and relative to the ganglionic area.

Statistical analyses - Between-group comparisons of morphometric data, considering the different strains and both times evaluated, were conducted using twoway ANOVA. The significance of difference between specific treatment means was determined by Bonferroni post-tests. In all cases, differences were considered statistically significant when $\mathrm{p}$ were $<0.05$.

\section{RESULTS}

Tissue parasitism and inflammatory process - Both the $\mathrm{Y}$ and Be-78 strains were able to infect the oesophagus and colon (Fig. 1, Table) and cause an inflammatory response (Fig. 1). During the acute phase, an inflammatory process was observed in both organs of animals infected with $\mathrm{Y}$ and Be-78 T. cruzi strains compared to the NI group. In the chronic phase, conventional PCR detected tissue parasitism only in the oesophagus of the Be-78-infected group, which may have been related to the persistent inflammatory process observed exclusively in this group.

Collagen neoformation - The biochemical evaluations of the collagen neoformation process demonstrated that compared to NI and Be-78-infected animals, animals Y-infected had increased total soluble collagen in the chronic phase (Fig. 2), with increased collagen type 
A Y Be-78
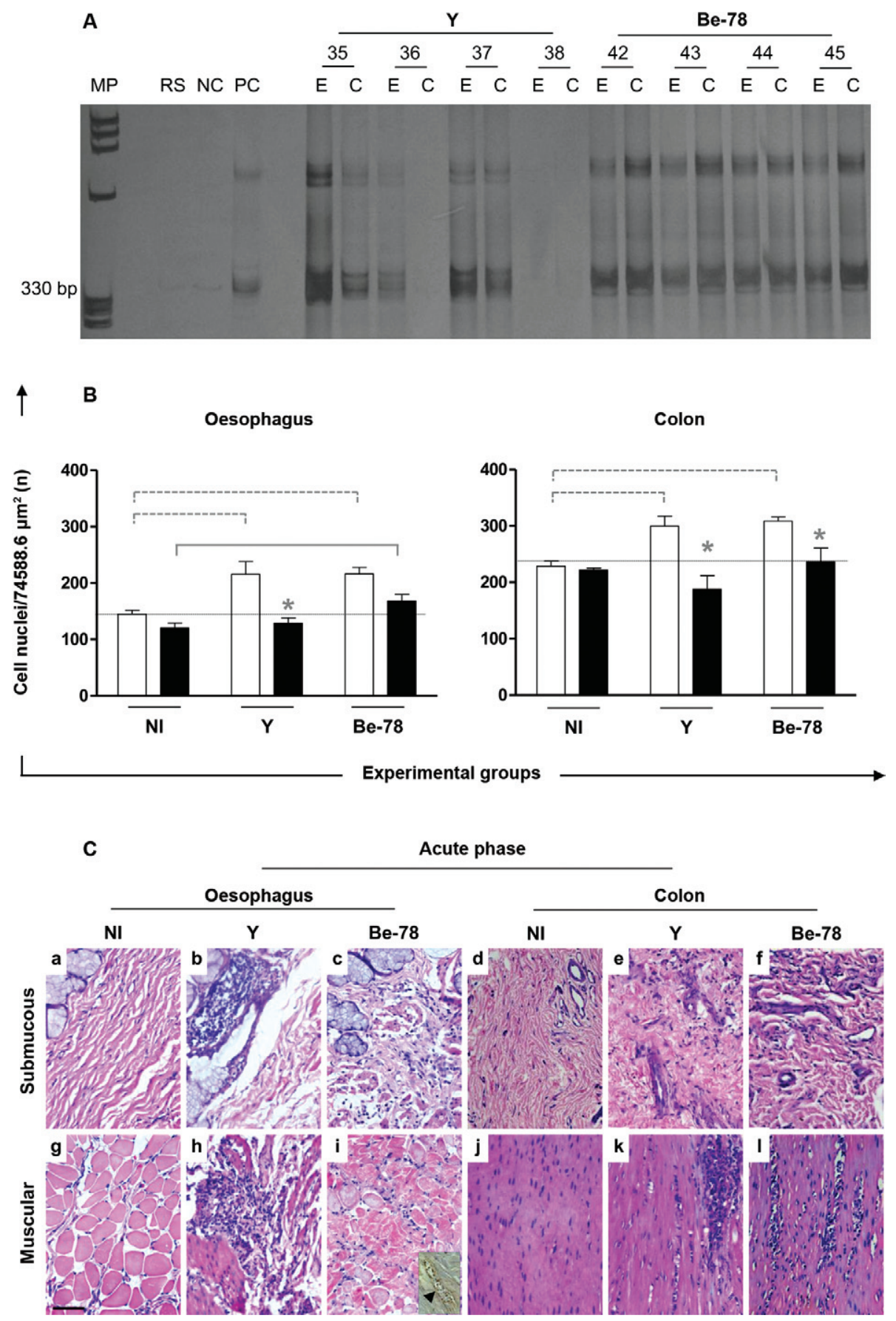

Fig. 1: tissue parasitism and inflammatory process evaluation in the oesophagus and colon of Beagle dogs experimentally infected with $\mathrm{Y}$ or Berenice-78 (Be-78) Trypanosoma cruzi strains. Groups with $n=4$. A: representative polyacrylamide gel showing the specific amplification of 330 bp fragments of kDNA minicircles of T. cruzi. [MW-DNA ( $\varphi$ X174); C: colon; E: oesophagus; MP: molecular pattern; NC: negative control/ negative sample; PC: positive control/positive sample; RS: rehydration solution]. The numbers represent codes of animals infected with the strains Y (35-38) or Be-78 (42-45) strains necropsied during the acute phase of experimental infection; B: morphometric analysis of the inflammatory process in noninfected (NI) animals, infected animals with Y strain (Y) and infected animals with Be-78 strain necropsied in acute ( $\square$ ) or chronic $(\boldsymbol{\square})$ phases. Data are represented as mean \pm standard error of the means. The dashed lines indicate significant differences between groups during the acute phase, solid lines indicate significant differences between groups during the chronic phase and the asterisk means significant difference between acute and chronic phases. Cut-off represented by the dotted line; C: oesophagus and colon (d, j) histological sections photomicrographs of NI Beagle dogs or dogs infected with Y or Be-78 T. cruzi strains. Oesophagus (a, g) and colon normal histological aspect in NI animals. Presence of inflammatory infiltrate in infected animals with Y (oesophagus: b, h; colon: e, k) and Be-78 strains (oesophagus: c, i; colon: $\mathrm{f}, 1$ ) accompanied by tissue parasitism (arrow head, insert in i, immunohistochemistry anti-T. cruzi). Haematoxylin-eosin. Bar $=50 \mu \mathrm{m}$. 
I deposition mainly in the intermuscular region in both the oesophagus and colon, consistent with intermuscular interstitial fibrosis.

Auerbach plexus - No significant difference in the number of neurons was observed between the groups for either organ (data not shown). In relation to neurons associated with degenerative injuries in the oesophagus, only Y strain-infected animals showed increased cell body area compared to NI animals and Be-78-infected animals during the chronic phase (data not shown). With regard to myenteric innervation as evaluated by PGP9.5-IR area in the ganglionic region, the oesophagus of infected animals showed significantly reduced innervation in the acute phase with both strains. In the chronic phase, myenteric denervation progressed only in animals infected with the Be-78 strain compared to NI and $\mathrm{Y}$ strain-infected animals (Figs 3, 4). In the colon, no differences were observed for the PGP9.5-IR area between the different groups (Fig. 3). Since the neuronal body count revealed no difference between the experimental groups, the denervation observed in infected animals seems to be related to loss of nerve filaments.
Enteroglial components - In Y group animals, there was a significant decrease in the GFAP-IR area in the oesophagus compared to the NI group during the acute phase. During the chronic phase, this reduction was observed only in the Be-78 group compared to the NI group (Figs 3, 4).

\section{DISCUSSION}

T. cruzi infection has been reproduced in various experimental models and the dog in particular presents a good representation of $\mathrm{ChD}$ manifestations, being able to reproduce acute infection followed by a long clinically asymptomatic period. In some cases, years later, cardiac fibrosis that progressed during the chronic phase has led to congestive heart failure (Andrade \& Andrade 1980, Tafuri et al. 1988, de Lana et al. 1988, 1992, Caliari et al. 2002). With regard to the digestive form of $\mathrm{ChD}$, although some authors have observed dilatation in canine model (Köberle 1957, Okumura \& Corrêa-Netto 1961), denervation and regressive neuronal lesions of the myenteric plexus do not appear to have a characteristic pattern; some studies report a pattern (Tafuri 1971, Caliari

TABLE

Tissue parasitism in the oesophagus and colon of Beagle dogs necropsied in acute or chronic phases from experimental infection with Y or Berenice-78 (Be-78) Trypanosoma cruzi strains

\begin{tabular}{|c|c|c|c|c|c|c|c|c|}
\hline \multirow[b]{3}{*}{$\begin{array}{l}\text { Experimental } \\
\text { groups }\end{array}$} & \multicolumn{4}{|c|}{ Oesophagus } & \multicolumn{4}{|c|}{ Colon } \\
\hline & \multicolumn{2}{|c|}{ Acute phase } & \multicolumn{2}{|c|}{ Chronic phase } & \multicolumn{2}{|c|}{ Acute phase } & \multicolumn{2}{|c|}{ Chronic phase } \\
\hline & $\begin{array}{l}\mathrm{PCR}^{-} \\
(\%)\end{array}$ & $\begin{array}{c}\mathrm{PCR}^{+} \\
(\%)\end{array}$ & $\begin{array}{l}\mathrm{PCR}^{-} \\
(\%)\end{array}$ & $\begin{array}{c}\mathrm{PCR}^{+} \\
(\%)\end{array}$ & $\begin{array}{l}\text { PCR }^{-} \\
(\%)\end{array}$ & $\begin{array}{l}\mathrm{PCR}^{+} \\
(\%)\end{array}$ & $\begin{array}{l}\text { PCR }^{-} \\
(\%)\end{array}$ & $\begin{array}{c}\mathrm{PCR}^{+} \\
(\%)\end{array}$ \\
\hline $\mathrm{Y}$ & 25 & 75 & 100 & 0 & 50 & 50 & 100 & 0 \\
\hline $\mathrm{Be}-78$ & 0 & 100 & 75 & 25 & 0 & 100 & 100 & 0 \\
\hline
\end{tabular}

the results are expressed as percentage of polymerase chain reaction $(\mathrm{PCR})^{+}$. Animals groups with $\mathrm{n}=4$.

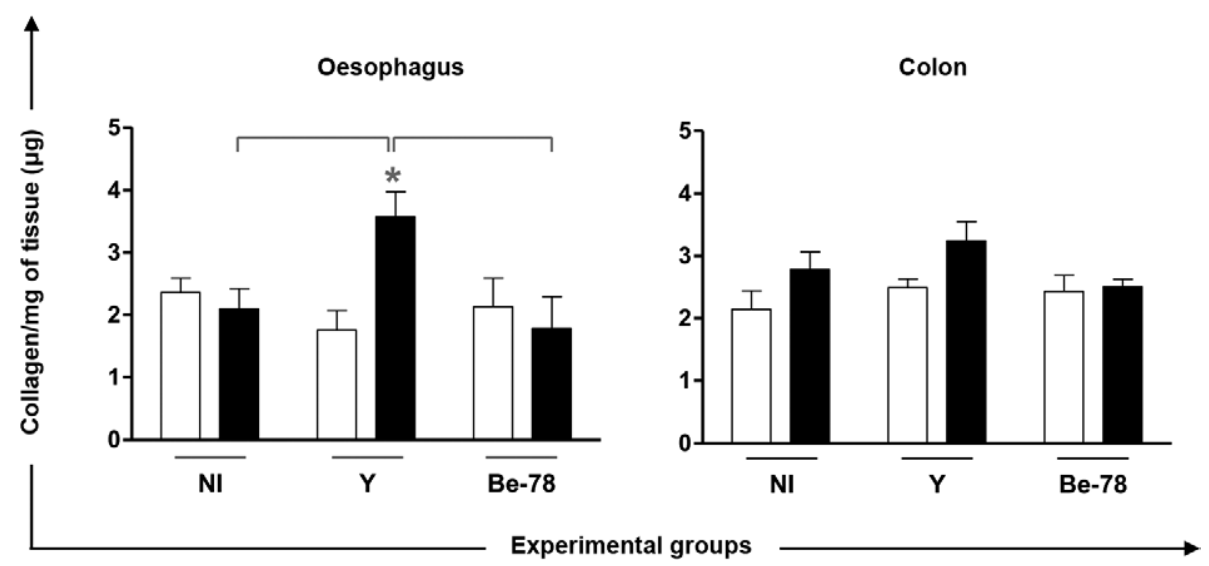

Fig. 2: quantitative evaluation of total soluble collagen in the oesophagus and colon of Beagle dogs necropsied in acute ( $\square$ ) or chronic ( $\square$ ) phases from experimental infection with Y or Berenice-78 (Be-78) strains of Trypanosoma cruzi. Data are expressed as means \pm standard error of the means. The solid lines indicate significant differences between groups during the chronic phase and the asterisk means significant difference between acute and chronic phases. Groups with $\mathrm{n}=4$. Be-78: infected animals with Be-78 strain; NI: noninfected animals; Y: infected animals with Y strain. 
et al. 1996), while others do not (Machado et al. 2001).

The motor disorders of the digestive tract in $\mathrm{ChD}$ are mainly related to ENS injury and these lesions may include neuronal degeneration; denervation, with neuronal or nerve fibre reduction (Köberle 1957, Okumura 1967, Tafuri 1971, Tafuri et al. 1979, Andrade \& Andrade 1980, Caliari et al. 1996, Santos 1998, da Silveira et al. 2005, 2007) and glial cell alterations (da Silveira et al. 2005, 2007, Nascimento et al. 2010). These changes seem to be directly associated with the inflammatory response and tissue parasitism maintenance (Tafuri \& Brener 1967, Tafuri 1970, 1971, Tafuri et al. 1971, Vago et al. 1996, 2003, Lages-Silva et al. 2001, da Silveira et al. 2005, ManoelCaetano et al. 2008). In this study, the oesophagus and colon were analysed in Beagle dogs infected with two $T$. cruzi strains (Y or Be-78) for up to 720 days of infection. Both strains were able to parasitise the oesophagus and colon of the dogs during the acute phase and this parasitism induced a moderate inflammatory infiltrate, distributed through the submucosal layer, muscularis mucosa and muscularis propria and in the periganglionar region. Similar changes were also observed by other authors in the oesophagus of dogs infected with different $T$. cruzi strains belonging to two different DTUs, Be-78 (TcII), 12SF and Colombiana (TcI) (Andrade \& Andrade 1980, Caliari et al. 1996, Santos 1998, Zingales et al. 2009).
In the chronic phase, positive PCR results for $T$. cru$z i$ were observed only in the oesophagus of the Be-78 group, reinforcing that the predominance of stout forms coincides with slow and progressive parasite multiplication (Andrade 1985). These results also agree with previous reports that the presence of T. cruzi kDNA and cytokines are more frequently associated with parasitism maintenance in the oesophagus as opposed to the colon (Lages-Silva et al. 2001, Ribeiro et al. 2008). In addition to parasitism maintenance, inflammation continues to be observed in this group, similar to that observed in dogs by others authors (Machado et al. 2001, Andrade \& Andrade 1980) or in T. cruzi-infected humans without the digestive form (Adad et al. 2001, da Silveira et al. $2005,2007)$. The inflammatory infiltrate can persist in the chronic phase, even if $\mathrm{ChD}$ clinical signs are absent; the dogs evaluated in this study were considered as not having the $\mathrm{ChD}$ digestive form and the tissue changes reaffirm that the undetermined form of $\mathrm{ChD}$ is not definitively characterised by normal histology. In fact it may even be related to an unfavourable prognosis leading to potential late clinical manifestations that progress to the apparent disease.

The collagen neoformation observed only in animals Y-infected may indicate that the inflammatory response was controlled in these animals, which permitted de-

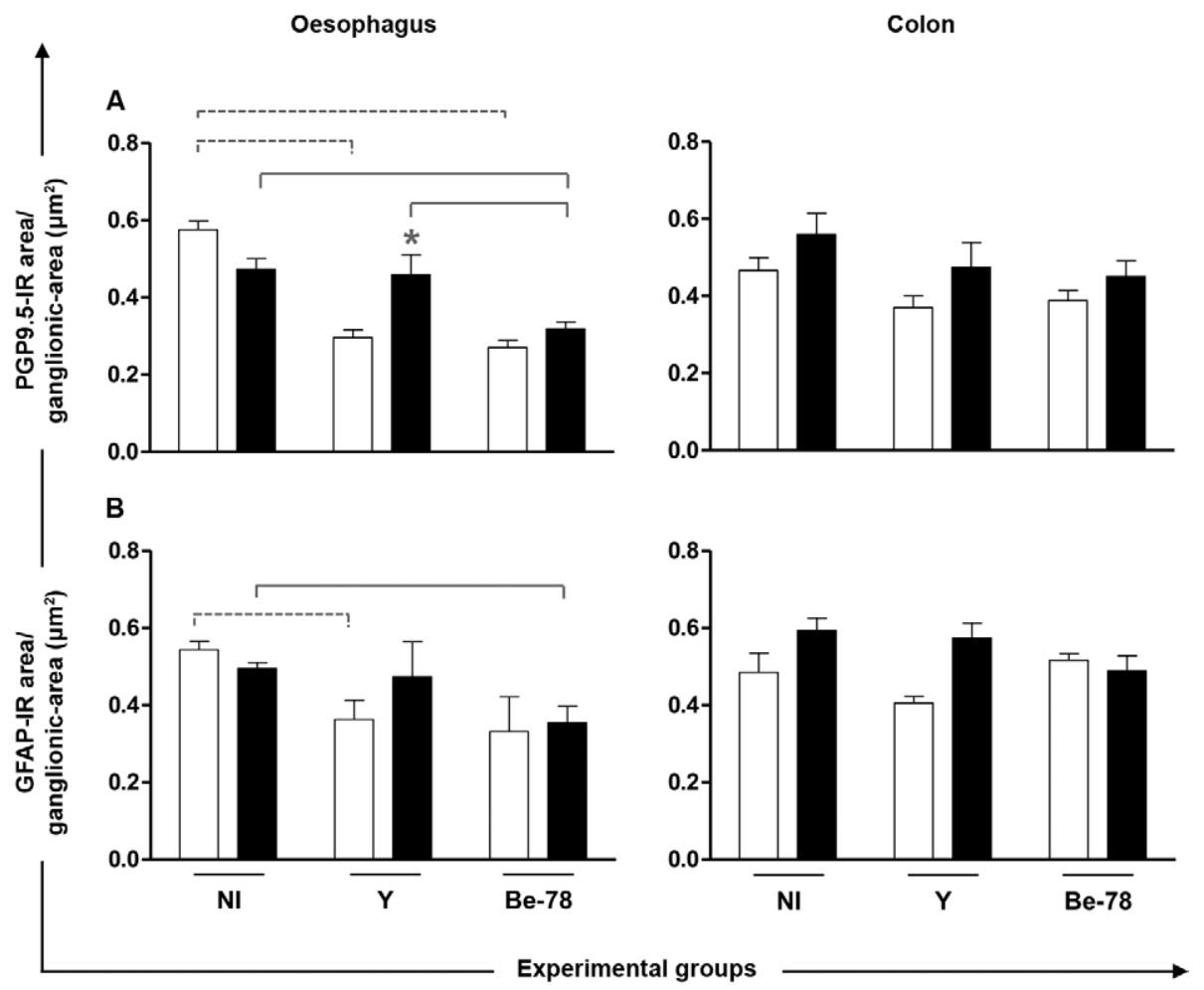

Fig. 3: morphometric analysis of Auerbach's plexus PGP9.5-immunoreactive (IR) neurons and nerve fibres (A) and glial fibrillary acidic protein (GFAP)-IR enteroglial components (B) in the oesophagus and colon of Beagle dogs necropsied in acute ( $\square$ ) or chronic ( $\square$ ) phases from experimental infection with Y or Berenice-78 (Be-78) strains of Trypanosoma cruzi. Data are expressed as means \pm standard error of the means. The dashed lines indicate significant differences between groups during the acute phase, the solid lines indicate significant differences between groups during the chronic phase and the asterisk means significant difference between acute and chronic. Groups with $n=4$. Be-78: infected animals with be-78 strain; NI: noninfected animals; Y: infected animals with Y strain. 
stroyed tissue areas to heal within two years of infection. However, the immunoregulatory response in animals infected with the Be-78 strain seemed to occur later, which agrees with findings from a murine model reported by Brener (1969), in which the response to infection with the Y strain was faster than with the Be-78 strain, resulting in earlier control of parasitaemia and tissue parasitism.

With regard to the ENS ganglionic components, experimental infection was able to cause denervation, related to the nerve fibre loss and $\mathrm{GFAP}^{+}$glial cell reduction. This was in contrast to observations from patients without the digestive form in which there was GFAP ${ }^{+}$ glial cell increase (da Silveira et al. 2007, Nascimento et al. 2010) and smaller loss of neuronal bodies (da Silveira et al. 2005), but not nerve fibre reduction; only in patients with the digestive form did these changes occur (da Silveira et al. 2007, Nascimento et al. 2010). These contradictory results reinforce that the study dogs, although considered asymptomatic, had some degree of ENS injury comparable to that observed in patients with gastrointestinal symptoms and this may be related to the specific T. cruzi strain. Our findings strengthen the evidence for denervation and $\mathrm{GFAP}^{+}$glial cell loss having an intimate relationship. Literature data indicate that glial cells have a role in an ENS defense mechanism against T. cruzi infection and are associated with prevention of organ denervation (Nascimento et al. 2010). Accordingly, the glial cell reduction observed in the oesophagus of Be-78 strain-infected dogs in the chronic phase, possibly in response to the inflammatory process, may be associated with a failure to contain tissue parasitism maintenance effects, which ultimately leads to denervation.
We observed that NI animals had apparent reduced innervation at the end of 720 days of follow-up. This finding is associated with senescence that causes dysmotility (Meciano-Filho et al. 1995). In ChD patients, radiographic findings indicate that oesophageal motility is more impaired in patients with advanced age compared with younger patients and this is also related to senescence (Dantas \& Aprile 2006). The reduction of the PGP9.5-IR area observed in the Be-78 group during the chronic phase was significantly greater than that caused by senescence in NI animals, however and for this reason it was considered to be denervation due to $\mathrm{ChD}$.

Comparing the pathogenic behaviour of the $\mathrm{Y}$ (composed by $91 \%$ of slender forms) and Be-78 (composed by $90 \%$ of stout forms) strains (Guedes et al. 2007), we observed that infection with the $\mathrm{Y}$ strain generally induced development of early changes that were reflected in an inflammatory response limited to the acute phase, with a healing process characterised by collagen neoformation within two years of infection. Furthermore, the denervation process and $\mathrm{GFAP}^{+}$glial cell reduction caused by this strain were significant only in the acute phase, returning to homeostasis at two years post-infection. These data are consistent with faster parasitaemia (Veloso et al. 2008) and control of tissue parasitism. In contrast, the persistence of parasites in the Be-78 group related to the absence of clinical symptoms in chronic experimental ChD suggests the participation of other factors, such as host genetics and immune response and phenomena associated with the parasite-host interaction, during the acute phase development of the $\mathrm{ChD}$ indeterminate form.

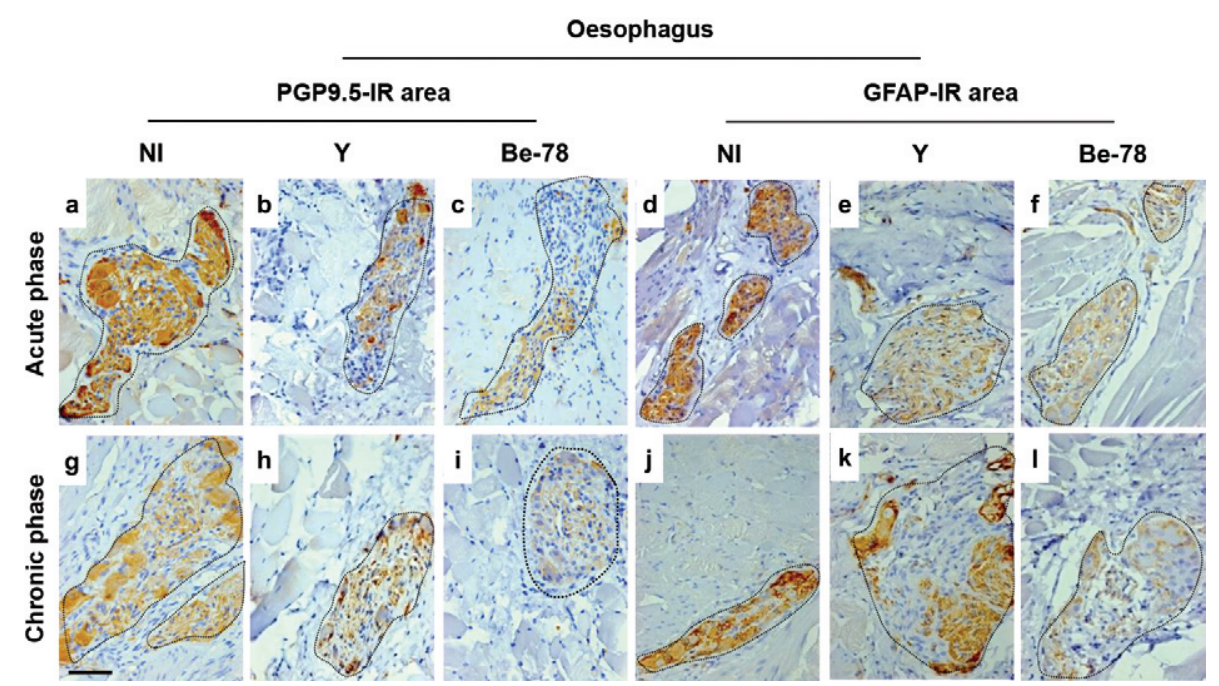

Fig. 4: photomicrographs of histological sections of the oesophagus showing Auerbach's plexus PGP9.5-IR neurons and nerve fibres and glial fibrillary acidic protein-immunoreactive (GFAP-IR) enteroglial components in noninfected (NI) Beagle dogs or dogs infected with Y or Berenice-78 (Be-78) of Trypanosoma cruzi and necropsied in acute or chronic phases of Chagas disease. PGP9.5-IR myenteric ganglia with normal appearance in NI animals (a) and moderate reduction of IR area in animals infected with Y (b) and Be-78 strains (c) in the acute phase. Myenteric ganglia with a slight reduction in the PGP9.5-IR area in NI animals $(\mathrm{g})$ or infected with the Y strain $(\mathrm{h})$ and intense reduction in immunomarked area in animals infected with Be-78 strain (i) in the chronic phase. GFAP-IR myenteric ganglia with normal appearance in NI (d) and infected animals with Be-78 strain (f) and reduction in GFAP-IR area in infected animals with Y strain (e) in the acute phase. Normal GFAP-IR myenteric ganglia in NI (j) and infected animals with the Y strain (k) and reduction in GFAP-IR area in infected animals with the Be-78 strain (l) in the chronic phase. Immunohistochemistry anti-PGP9.5 in a-c, g-i. Immunohistochemistry anti-GFAP in d-f, j-1. Bar $=50 \mu \mathrm{m}$. 
Furthermore, genetic variability of the parasite and the histotropism phenomena seem to influence clinical progression of the disease. The presence of distinct $T$. cruzi genetic profiles in the different organs has been shown by using parasite isolates obtained directly from the heart and oesophagus of chagasic patients with cardiac and oesophageal involvement. These distinct profiles indicate infection with polyclonal strains and a preferential histotropism between the populations, sufficient to influence the distinct clinical forms' pathogenesis and development (Vago et al. 1996). Although in this work infection with two strains was independent, a distinct selection may be suggested in the chronic phase, since heart tissues show a higher positivity by PCR for the Y strain (Veloso et al. 2008), while the oesophagus was positive only for Be-78 strain in our study. This hypothesis is further strengthened by data obtained by Guedes et al. (2007) during an evaluation of Beagle hearts, in which $80 \%$ of animals Y-infected showed cardiomegaly and cardiac abnormalities, chronic inflammation and fibrosis. In contrast, only $20 \%$ of dogs infected with the Be-78 strain had these manifestations.

Given pathological changes persisting over 720 days of infection, including parasitism and tissue inflammation, as well as other findings related to the ganglionic components of Auerbach's plexus, especially in animals infected with the Be-78 strain, we suggest that the absence of clinical signs and symptoms does not necessarily indicate histological normality. This confirms the need for more studies addressing the self-limited or progressive character of the indeterminate form of $\mathrm{ChD}$ manifestations. Immunopathological studies indicate that the indeterminate form represents an ideal situation for both the parasite and host, in which there is a balance between the immune response capable of maintaining the parasitism at low levels while still remaining in control and avoiding cytotoxic mechanisms (Dutra et al. 2009). The direct influence of immune mechanisms in chronic lesions must be understood along with $\mathrm{ChD}$ in both its determinate and indeterminate forms.

In summary, although morphologically distinct, both strains were able to reach and parasitise the oesophagus and colon inducing a considerable inflammation process in the submucosal and muscular layers and also adjacent to myenteric ganglia, however, the animals infected with Y strain appear to control parasitism and return the immune system to homeostasis, while animals infected with Be-78 strain keep parasitism until the end of inflammation at 720 days. Regarding the ENS, the lesions induced by $\mathrm{Y}$ strain appear to be self-limiting as those induced by infection with Be-78 strain are longer lasting and may perhaps present more progressive character. In this context, we confirm that the morphological differences interfere with the initial development of the immune response of the host which in the long-term can determine the success of tissue parasitism control and associated injuries.

\section{ACKNOWLEDGEMENTS}

To the kennel staff of the UFOP, for dedication throughout the execution of this project.

\section{REFERENCES}

Adad SJ, Andrade DCS, Lopes ER, Chapadeiro E 1991. Contribuição ao estudo da anatomia patológica do megaesôfago chagásico. Rev Inst Med Trop São Paulo 33: 443-450.

Adad SJ, Cançado CG, Etchebehere RM, Teixeira VPA, Gomes UA, Chapadeiro E, Lopes ER 2001. Neuron count reevaluation in the myenteric plexus of chagasic megacolon after morphometric neuron analysis. Virchows Arch 438: 254-258.

Andrade ZA 1985. A patologia da doença de Chagas no homem. Ann Soc Belg Med Trop 65: 15-30.

Andrade ZA 2005. A forma indeterminada da doença de Chagas em tempos de controle do Triatoma infestans. Rev Patol Trop 34: 105-111.

Andrade ZA, Andrade SG 1980. A patologia da doença de Chagas experimental no cão. Mem Inst Oswaldo Cruz 75: 77-95.

Ávila H, Gonçalves AM, Nehme NS, Morel CM, Simpson L 1990. Schizodeme analysis of Trypanosoma cruzi stocks from South and Central America by analysis of PCR-amplified minicircle variable region sequences. Mol Biochem Parasitol 42: 175-188.

Barbosa BJP, Araújo EJA, Silva AV, Sant'Ana DMG 2009. Atrofia neuronal mientérico no íleo de ratos infectados cronicamente por uma cepa genótipo I de Toxoplasma gondii. Arq Ciênc Vet Zoo UNIPAR 12: 101-108.

Brener Z 1969. The behaviour of slender and stout forms of Trypanosoma cruzi in the blood-stream of normal and immune mice. Ann Trop Med Parasitol 63: 215-220.

Buniatian GH, Hartmann HJ, Traub P, Wiesinger H, Albinus M, Nagel W, Shoeman R, Mecke D, Weser U 2002. Glial fibrillary acidic protein-positive cells of the kidney are capable of raising a protective biochemical barrier similar to astrocytes: expression of metallothionein in podocytes. Anat Rec 267: 296-306.

Caliari ER, Caliari MV, de Lana M, Tafuri WL 1996. Estudo quantitativo e qualitativo dos plexos de Auerbach e Meissner do esôfago de cães inoculados com o Trypanosoma cruzi. Rev Soc Bras Med Trop 29: 17-20.

Caliari MV, de Lana M, Cajá RAF, Carneiro CM, Bahia MT, Santos CAB, Magalhães GA, Sampaio IBM, Tafuri WL 2002. Immunohistochemical studies in acute and chronic canine chagasic cardiomyopathy. Virchows Arc 441: 69-76.

Castro C, Hernandez EB, Rezende J, Prata A 2012. Occurrence of dolichocolon without megacolon in chronic Chagas disease patients. Rev Soc Bras Med Trop 45: 353-356.

Castro C, Macedo V, Resende JM, Prata A 1994. Estudo radiológico longitudinal do esôfago em área endêmica de doença de Chagas em um período de treze anos. Rev Soc Bras Med Trop 27: 227-233.

Castro C, Prata A, Macedo V 2001. Estudo clínico durante 13 anos de 190 chagáscios crônicos de Mambaí, Goiás, Brasil. Rev Soc Bras Med Trop 34: 309-318.

Chagas C 1909. Nova trypanozomiaze humana. Estudos sobre a morfolojia e o ciclo evolutivo do Schizotrypanum cruzi n. gen., n. sp., ajente etiolojico de nova entidade morbida do homem. Mem Inst Oswaldo Cruz 1: 159-218.

Coura JR, de Abreu LL, Pereira JB, Willcox HP 1985. Morbidade da doença de Chagas. IV. Estudo longitudinal de dez anos em Pains e Iguatama, Minas Gerais, Brasil. Mem Inst Oswaldo Cruz 80: 73-80.

da Silveira ABM, Arantes RM, Vago AR, Lemos EM, Adad SJ, Correa-Oliveira R, D'Avila Reis D 2005. Comparative study of the presence of Trypanosoma cruzi kDNA, inflammation and den- 
ervation in chagasic patients with and without megaesophagus. Parasitology 131: 627-634.

da Silveira ABM, Freitas MAR, Oliveira EC, Neto SG, Luquetti AO, Furness JB, Correa-Oliveira R, D'Avila Reis D 2009. Glial fibrillary acidic protein and S-100 colocalization in the enteroglial cells in dilated and nondilated portions of colon from chagasic patients. Hum Pathol 40: 244-251.

da Silveira ABM, Lemos EM, Adad SJ, Correa-Oliveira R, Furness JB, D’Avila-Reis D 2007. Megacolon in Chagas disease: a study of inflammatory cells, enteric nerves and glial cells. Hum Pathol 38: $1256-1264$.

Dantas RO, Aprile LRO 2006. Comparison of esophageal motility impairment caused by Chagas disease in two age groups. Arq Gastroenterol 43: 196-200.

de Lana M, Chiari CA 1986. Caracterização biológica comparativa das cepas Berenice e Berenice-78 de Trypanosoma cruzi isoladas da mesma paciente em diferentes períodos. Mem Inst Oswaldo Cruz 81: 247-253.

de Lana M, Chiari, E, Tafuri WL 1992. Experimental Chagas disease in dogs. Mem Inst Oswaldo Cruz 87: 59-71.

de Lana M, Tafuri WL, Caliari MV, Bambirra EA, Chiari CA, RiosLeite VH, Barbosa AJA, Toledo MJO, Chiari E 1988. Fase crônica cardíaca fibrosante da tripanossomíase cruzi experimental no cão. Rev Soc Bras Med Trop 21: 113-121.

Dutra WO, Menezes CAS, Villani FNA, da Costa GC, da Silveira ABM, d'Ávila-Reis D, Gollob KJ 2009. Cellular and genetic mechanisms involved in the generation of protective and pathogenic immune response in human Chagas disease. Mem Inst Oswaldo Cruz 104 (Suppl. I): 208-218.

Guedes PMM, Veloso VM, Caliari MV, Carneiro CM, Souza SM, de Lana M, Chiari E, Bahia MT, Galvão LMC 2007. Trypanosoma cruzi high infectivity in vitro is related to cardiac lesions during long-term infection in Beagle dogs. Mem Inst Oswaldo Cruz 102: 141-147.

Iantorno G, Bassotti G, Kogan Z, Lumi CM, Cabanne AM, Fisogni S, Varrica LM, Bilder CR, Munõz JP, Liserre B, Morelli A, Villanacci V 2007. The enteric nervous system in chagasic and idiopathic megacolon. Am J Surg Pathol 31: 460-468.

Köberle F 1957. Patogenia da moléstia de Chagas. Estudos dos órgãos musculares ocos. Rev Goiana Med 3: 155-180.

Köberle F, Alcântara FG 1960. Mecanismo de destruição neuronal do sistema nervoso periferico na molestia de Chagas. Hospital 57: $1057-1962$

Lages-Silva E, Crema E, Ramirez LE, Macedo AM, Pena SD, Chiari E 2001. Relationship between Trypanosoma cruzi and human chagasic megaesophagus: blood and tissue parasitism. Am J Trop Med Hyg 65: 435-441.

Machado EMM, Camilo Jr DJ, Pinheiro SW, Lopes ER, Fernades AJ, Dias JCP, Adad SJ 2001. Morphometry of submucous and myenteric esophagic plexus of dogs experimentally reinfected with Trypanosoma cruzi. Mem Inst Oswaldo Cruz 96: 545-548.

Maltos KL, Menezes GB, Caliari MV, Rocha OA, Santos JM, Alves DL, Duarte ID, Francischi JN 2004. Vascular and cellular responses to pro-inflammatory stimuli in rat dental pulp. Arch Oral Biol 49: 443-450.

Manoel-Caetano FS, Carareto CMA, Borim AA, Miyazaki K, Silva AE 2008. kDNA gene signatures of Trypanosoma cruzi in blood and esophageal mucosa from chronic chagasic patients. Trans $R$ Soc Trop Med Hyg 102: 1102-1107.

Meciano-Filho J, Carvalho VC, Souza RR 1995. Nerve cell loss in the myenteric plexus of the human esophagus in relation to age: a preliminary investigation. Gerontology 41: 18-21.
Mendes HMF, Escobar A, Vasconcelos AC, Zucoloto S, Alves GES, Faleiros RR 2009a. Alterações morfométricas no plexo mientérico do cólon menor eqüino distendido experimentalmente. Pesq Vet Bras 29: 557-562.

Mendes JB, Rocha MA, Araújo FA, Moura SAL, Ferreira MAND, Andrade SP 2009b. Differential effects of rolipram on chronic subcutaneous inflammatory angiogenesis and on peritoneal adhesion in mice. Microvasc Res 78: 265-271.

Moura SAL, Negri G, Salatino A, Lima LDC, Dourado LPA, Mendes JB, Andrade SP, Ferreira MAND, Cara DC 2009. Aqueous extract of Brazilian green propolis: primary components, evaluation of inflammation and wound healing by using subcutaneous implanted sponges. Evid Based Complement Alternat Med 2011; 2011: 748283 .

Nascimento RD, Lisboa AS, Fujiwara RT, Freitas MAR, Adad SJ, Correa-Oliveira R, D'Ávila-Reis D, da Silveira ABM 2010. Characterization of enteroglial cells and denervation process in chagasic patients with and without megaesophagus. Hum Pathol 41: 528-534.

Okumura M 1967. Contribuição para o estudo das lesões dos neurônios do plexo mioentérico do cólon na moléstia de Chagas experimental no camundongo branco (Mus musculus). Rev Hosp Clin Fac Med Univ São Paulo 22: 192-203.

Okumura M, Corrêa-Netto A 1961. Produção experimental de megas em animais inoculados com Trypanosoma cruzi. Rev Hosp Clin Fac Med Univ São Paulo 16: 338-341.

Prata A 2001. Clinical and epidemiological aspects of Chagas disease. Lancet Infect Dis 1: 92-100.

Ribeiro BM, Crema E, Rodrigues Jr V 2008. Analysis of the cellular immune response in patients with the digestive and indeterminate forms of Chagas disease. Hum Immunol 69: 484-489.

Ribeiro Dos Santos, Hudson L 1980. Trypanosoma cruzi: immunological consequences of parasite modification of host cells. Clin Exp Immunol 40: 36-41.

Ribeiro Dos Santos, Hudson L 1981. Denervation and the immune response in mice infected with Trypanosoma cruzi. Clin Exp Immunol 44: 349-354.

Santos CAB 1998. Estudo morfológico e morfométrico do esôfago do cão normal e na fase aguda da tripanosomíase cruzi experimental com referência especial ao plexo mientérico, Thesis, Universidade Federal de Minas Gerais, Belo Horizonte, 74 pp.

Santos FR, Pena SDJ, Epplen JT 1993. Genetic and population study of a Y-linked tetranucleotide repeat DNA polymorphism with a simple non-isotopic technique. Hum Genet 90: 655-656.

Silva LHP, Nussenzweig V 1953. Sobre uma cepa de Trypanosoma cruzi altamente virulenta para o camundongo branco. Folia Clin Biol 20: 191-203.

Tafuri WL 1957. Auerbach's plexus in the guinea pig: a quantitative study of the ganglia and nerve cells of the ileum, caecum and colon. Acta Anat 31: 522-530.

Tafuri WL 1970. Pathogenesis of lesions of the autonomic nervous system of the mouse in experimental acute Chagas disease: light and electron microscope studies. Am J Trop Med Hyg 19: 405-417.

Tafuri WL 1971. Light and electron microscopy studies of the autonomic nervous system in experimental and human American trypanosomiasis. Virchows Arch A Pathol Pathol Anat 354: 136-149.

Tafuri WL, Brener Z 1967. Lesões dos plexos de Meissner e de Auerbach do intestino do camundongo albino na fase crônica da tripanosomiase cruzi experimental. Rev Inst Med Trop São Paulo 9: $149-154$. 
Tafuri WL, de Lana M, Chiari E, Caliari MV, Bambirra EA, RiosLeite VH, Barbosa JA 1988. O cão como modelo experimental para o estudo da história natural da doença de Chagas. Rev Soc Bras Med Trop 21: 77.

Tafuri WL, Lima-Pereira FE, Bogliolo L, Raso P 1979. Lesões do sistema nervoso autônomo e do tecido muscular estriado esquelético na fase crônica da tripanosomose cruzi experimental. Estudos ao microscópio óptico e eletrônico. Rev Goiana Med 25: 61-67.

Tafuri WL, Maria TA, Lopes ER 1971. Myenteric plexus lesions in the esophagus, jejunum and colon of chronic chagasic patients. Electron microscopy study. Rev Inst Med Trop São Paulo 13: 7691.

Teixeira ARL, Roters FA, Mott KE 1970. Acute Chagas disease. GMBahia 3: 176-186.

Vago AR, Macedo AM, Adad SJ, Reis DA, Corrêa-Oliveira R 1996. PCR detection of Trypanosoma cruzi DNA in esophageal tissues of patients with chronic Chagas disease. Lancet 348: 891-892.

Vago AR, Silva DM, Adad SJ, Correa-Oliveira R, D’Ávila Reis D 2003. Chronic Chagas disease: presence of parasite DNA in esophagus without megaesophagus. Trans R Soc Trop Med Hyg 97: 308-309.
Veloso VM, Guedes PMM, Andrade IM, Caldas IS, Martins HR, Carneiro CM, Machado-Coelho GLL, de Lana M, Galvão LMC, Bahia MT, Chiari E 2008. Trypanosoma cruzi: blood parasitism kinetics and their correlation with heart parasitism intensity during long-term infection of Beagle dogs. Mem Inst Oswaldo Cruz 103: $528-534$

Virreira M, Serrano G, Maldonado L, Svoboda M 2006. Trypanosoma cruzi: typing of genotype (sub)lineages in megacolon samples from Bolivian patients. Acta Trop 100: 252-255.

Von Boyen GB, Steinkamp M, Reinshagen M, Schafer KH, Adler G, Kirsch J 2004. Proinflammatory cytokines increase glial fibrillary acidic protein expression in enteric glia. Gut 53: 222-228.

Zingales B, Andrade SG, Briones MRS, Campbell DA, Chiari E, Fernandes O, Guhl F, Lages-Silva E, Macedo AM, Machado CR, Miles MA, Romanha AJ, Sturm NR, Tibayrenc M, Schijman AG 2009. A new consensus for Trypanosoma cruzi intraspecific nomenclature: second revision meeting recommends TcI to TcVI. Mem Inst Oswaldo Cruz 104: 1051-1054.

Zingales B, Souto RP, Mangia RH, Lisboa CV, Campbell DA, Coura JR, Jansen A, Fernandes O 1998. Molecular epidemiology of American trypanosomiasis in Brazil based on dimorphisms of rRNA and mini-exon gene sequences. Int J Parasitol 28: 105-112. 